\title{
Comparison of the effects of propofol and pentobarbital on hydrogen peroxide-stimulated hepatic SNU761 cells
}

\author{
Ji Yeon Lee ${ }^{2}$, Jin-Woo Shin ${ }^{1}$, Eun Ho Lee ${ }^{1}$, Seung-Hye Baek ${ }^{1}$, Seung Woo Ku ${ }^{1}$, and Joung Uk Kim ${ }^{1}$ \\ ${ }^{1}$ Department of Anesthesiology and Pain Medicine, Asan Medical Center, University of Ulsan College of Medicine, \\ ${ }^{2}$ Department of Anesthesiology and Pain Medicine, Korea Institute of Radiological and Medical Sciences, Seoul, Korea
}

Background: Propofol and barbiturates are both known to protect cells of several organs against ischemia/ reperfusion injury, but there are few reports on any possible protective effects on human hepatocytes. We investigated the activities of both agents on human hepatic SNU761 cells under hydrogen peroxide $\left(\mathrm{H}_{2} \mathrm{O}_{2}\right)$-induced oxidative stress.

Methods: To determine whether propofol and pentobarbital protect hepatocytes from $\mathrm{H}_{2} \mathrm{O}_{2}$-induced toxicity, we used SNU761 cells, a human hepatocellular carcinoma (HCC) cell line. Cells were pretreated with different dosages $(1,10,50 \mu \mathrm{M})$ of propofol or pentobarbital $(1,10,50,100,400 \mu \mathrm{M}) 30 \mathrm{~min}$ before $\mathrm{H}_{2} \mathrm{O}_{2}$ application. Lactate dehydrogenase (LDH) was measured to assess and quantify cell death. To determine the nature of cell death, treated hepatocytes were doubly stained with fluorescein isothiocyanate (FITC)-labeled Annexin V and propidium iodide (PI), and analyzed by flow cytometry.

Results: Pretreatment with propofol, but not pentobarbital, suppressed $\mathrm{H}_{2} \mathrm{O}_{2}$-induced LDH release. In Annexin V-FITC/PI binding analysis, propofol decreased the number of necrotic and late apoptotic cells, but no significant decreases in such cell numbers were seen when pentobarbital was used.

Conclusions: Unlike pentobarbital, propofol, at clinical concentrations, protected SNU-761 HCC cells against oxidative stress. (Korean J Anesthesiol 2010; 58: 277-282)

Key Words: Apoptosis, Hepatocyte, Hydrogen peroxide, Necrosis, Pentobarbital, Propofol.

Received: September 15, 2009. Revised: October 5, 2009. Accepted: November 2, 2009.

Corresponding author: Seung Woo Ku, M.D., Department of Anesthesiology and Pain Medicine, Asan Medical Center, University of Ulsan College of Medicine, 388-1, Pungnap-dong, Songpa-gu, Seoul 138-762, Korea. Tel: 82-2-3010-3868, Fax: 82-2-470-1363, E-mail: swkoo@amc. seoul.kr

This work was supported by a grant from the Asan Institute for Life Sciences, Seoul, Korea [Grant Number: 2007-398].

(c) This is an open-access article distributed under the terms of the Creative Commons Attribution Non-Commercial License (http:// creativecommons.org/licenses/by-nc/3.0/), which permits unrestricted non-commercial use, distribution, and reproduction in any medium, provided the original work is properly cited. 


\section{Introduction}

Liver injury caused by oxidative stress may occur under many clinical conditions, including liver surgery, transplantation surgery, the use of extracorporeal circulation in cardiac or vascular surgery and hemorrhagic, cardiogenic, or septic shock states followed by resuscitation $[1,2]$, and it could increase the morbidity and mortality of patient $[3,4]$. Although hepatocytes have an antioxidant defence system to remove or neutralize reactive oxygen species (ROS), excessive production of ROS such as hydrogen peroxide $\left(\mathrm{H}_{2} \mathrm{O}_{2}\right)$, occurring during the reperfusion period, results in an imbalance between pro-oxidants and antioxidants and usually leads to cellular dysfunction and tissue injury [5]. Thus, suppression of oxidative stress caused by ROS could reduce liver damage and ameliorate outcome of patients.

Propofol (2, 6-diisopropylphenol) and barbiturate, highly lipid-soluble anaesthetics, are both known to have antioxidant activities, protecting against lipid peroxidation [6], and both agents are often used in several clinical conditions to reduce cerebral edema during liver transplantation in fulminant hepatic failure (FHF) patients $[7,8]$. However, whether the antioxidant activities of propofol and pentobarbital protect hepatocytes exposed to oxidative stress is unclear.

Cell death can be categorized into apoptosis and necrosis. Apoptosis, or programmed cell death, is an active process characterized by cytoplasmic shrinkage, chromatin condensation, nuclear fragmentation, and activation of caspases [9]. In addition, phosphatidylserine (PS) is exposed on the external surface of the cell in the early phase of apoptosis, and this exposure precedes membrane damage and DNA fragmentation [10]. On the other hand, necrosis is passive, and is characterized by cell swelling, rupture of the plasma membrane, and cell lysis, with leakage of cytoplasmic components such as lactate dehydrogenase (LDH) [9].

It is known that direct exposure of hepatocytes to exogenous oxidants including $\mathrm{H}_{2} \mathrm{O}_{2}$ can induce both apoptotic and necrotic cell death [11]. In the current study, we explored the modes of cell death (apoptosis and/or necrosis) induced by $\mathrm{H}_{2} \mathrm{O}_{2}$ in hepatic cell and compared the protective effects of propofol and pentobarbital.

\section{Materials and Methods}

Propofol was obtained from AstraZeneca Pharmaceuticals (Macclesfield, Cheshire, UK), and pentobarbital sodium salt was from Sigma (St. Louis, MO, USA). The LDH assay kit (CytoTox $96^{\circledR}$ Non-Radioactive Cytotoxicity Assay) was from Promega (Madison, WI, USA). RPMI-1640 with L-glutamine, fetal bovine serum, and an antibiotic-antimycotic mixture (penicillin-streptomycin-amphotericin B) were purchased from Gibco BRL (New York, NY, USA). $\mathrm{H}_{2} \mathrm{O}_{2}$ was purchased from Sigma. Fluorescein isothiocyanate (FITC)-labeled Annexin V and propidium iodide (PI) were from BD Biosciences (San Jose, CA, USA).

The SNU-761 human hepatocellular carcinoma (HCC) cell line was purchased from the Korean Cell Line Bank [12]. Cells were cultured in RPMI-1640 with L-glutamine (300 mg/L) and HEPES (25 mM) containing $10 \%(\mathrm{v} / \mathrm{v})$ fetal bovine serum and $10,000 \mathrm{units} / \mathrm{ml}$ of penicillin, $10,000 \mu \mathrm{g} / \mathrm{ml}$ of streptomycin, and $25 \mu \mathrm{g} / \mathrm{ml}$ of amphotericin $\mathrm{B}$ at $37^{\circ} \mathrm{C}$ in a humidified incubator under $95 \%$ air $/ 5 \% \mathrm{CO}_{2}$. Culture medium was replaced every 2 days. Three days after plating, cells were challenged with $\mathrm{H}_{2} \mathrm{O}_{2}$ at variable concentrations and different durations.

Varying concentrations of propofol $(1,10,50 \mu \mathrm{M})$ or pentobarbital $(10,50,100,400 \mu \mathrm{M})$ were added to cell culture medium. Before induction of cell death by $\mathrm{H}_{2} \mathrm{O}_{2}(125 \mu \mathrm{M})$, cells were pretreated with different drug doses for $30 \mathrm{~min}$ and $\mathrm{H}_{2} \mathrm{O}_{2}$ was then added; incubation continued for $6 \mathrm{~h}$.

$\mathrm{LDH}$ is normally present in the cytoplasm of hepatocytes. In response to cell damage, $\mathrm{LDH}$ is released from cells. Therefore, to measure necrotic cell death, we assayed LDH levels and calculated percentages of LDH release to the medium. LDH activity was measured spectrophotometrically using a commercial kit. The percentage of LDH release was calculated by $[\mathrm{LDH}]_{\text {test }} /[\mathrm{LDH}]_{\text {control }} \times 100$ where $[\mathrm{LDH}]_{\text {test }}$ was the $\mathrm{LDH}$ level of the test medium and $[\mathrm{LDH}]_{\text {control }}$ was the measured LDH level in control medium.

To assess the cell death modes induced by $\mathrm{H}_{2} \mathrm{O}_{2}$, treated SNU-761 HCC cells were doubly stained with Annexin V-FITC and PI and analyzed by flow cytometry. Exposure of PS on the external cell surface occurs in the early phase of apoptotic cell death, during which time the cell membrane remains intact [13]. Therefore, simultaneous use of Annexin V (which binds specifically to PS) and a non-vital dye (such as PI; exclusion of the dye from cells indicates cell membrane integrity) is valuable in discriminating between apoptosis and necrosis [10].

Annexin V-FITC/PI double staining of cells was achieved using an Annexin V-FITC apoptosis detection kit. Briefly, both floating and adherent cells were collected and analyzed; $1 \times$ $10^{6}$ cells/well were plated on a 12 -well plate. Cells were washed with PBS and collected by trypsinization. After centrifugation at $400 \times \mathrm{g}$ for $5 \mathrm{~min}$ at $4^{\circ} \mathrm{C}$, cells were washed twice with cold PBS and resuspended in $1 \times$ Annexin $\mathrm{V}$ binding buffer. One hundred microliter amounts of cell suspension were transferred to test tubes to which were added $5 \mu \mathrm{l}$ of FITC-labeled Annexin V and $5 \mu \mathrm{l}$ of PI solution. The cells were gently vortexed and incubated for $15 \mathrm{~min}$ at room temperature in the dark. After addition of $200 \mu \mathrm{l} 1 \mathrm{x}$ binding buffer to each tube, cells were analyzed on a FACSCalibur flow cytometer (BD Biosciences, San Jose, CA, 
USA). Annexin V-FITC and PI emissions were detected in the FL 1 and FL 2 channels. The Annexin V-FITC-/PI- population was considered to reflect normal healthy cells, whereas Annexin V-FITC + /PI- cells were taken to show early apoptosis. Annexin V-FITC $+/$ PI + cells were in late apoptosis or necrosis, whereas Annexin V-FITC-/PI+ cells were necrotic [11]. The percentages of normal, early apoptotic, late apoptotic, and necrotic cells were calculated using the CellQuest Pro software program (r 2000 Becton Dickinson, Hertfordshire, UK).

Statistical analyses were performed employing the SigmaStat program (version 3.10; Systat software; Chicago, IL, USA). Multiple groups were compared using one-way analysis of variance (ANOVA) or the Kruskal-Wallis one-way ANOVA on ranks followed by multiple comparisons using the Tukey post hoc test when appropriate. For all comparisons, a $\mathrm{P}$ value less than 0.05 was considered statistically significant. Data shown are mean \pm SD unless stated otherwise.

\section{Results}

Pretreatment with propofol at 1,10 , or $50 \mu \mathrm{M}$ gradually suppressed $\mathrm{H}_{2} \mathrm{O}_{2}$-induced LDH release, with the two higher concentrations showing significant release inhibition $(\mathrm{P}<$ 0.05) (Fig. 1A). Pretreatment with pentobarbital at 10,50, or $100 \mu \mathrm{M}$ did not suppress $\mathrm{H}_{2} \mathrm{O}_{2}$-induced LDH release; in fact, pentobarbital at $400 \mu \mathrm{M}$ significantly $(\mathrm{P}<0.05)$ increased such release (Fig. 1B).

Annexin V-FITC binding analysis and PI staining were performed to identify cells undergoing apoptotic and necrotic death, respectively. SNU-761 HCC cells were treated with 0, 125 , or $250 \mu \mathrm{M}$ of $\mathrm{H}_{2} \mathrm{O}_{2}$ for $6 \mathrm{~h}$ and next stained with Annexin V-FITC/PI. As shown in Fig. 2, $\mathrm{H}_{2} \mathrm{O}_{2}$ decreased the proportion of normal cells, and increased the percentages of apoptotic and necrotic cells, in a dose-dependent manner.

After treatment of SNU-761 HCC cells with $\mathrm{H}_{2} \mathrm{O}_{2}$ for $6 \mathrm{~h}$ at a concentration of $125 \mu \mathrm{M}$, necrotic and late apoptotic cells increased in number. As shown in Fig. 2, propofol decreased these numbers $(\mathrm{P}<0.05)$, but pentobarbital caused no significant decrease in numbers of necrotic or apoptotic cells.

\section{Discussion}

In this study, we examined and compared the effects of propofol and pentobarbital on hepatocyte death induced by $\mathrm{H}_{2} \mathrm{O}_{2}$ in vitro. The results indicate that propofol, but not pentobarbital, exerts a protective effect on hepatocytes exposed to $\mathrm{H}_{2} \mathrm{O}_{2}$ oxidant stress.

To investigate possible protective roles of propofol and pentobarbital during oxidant-mediated cell death, we used $\mathrm{H}_{2} \mathrm{O}_{2}$ as a stress inducer. ROS, including $\mathrm{H}_{2} \mathrm{O}_{2}$, cause a variety of cell and tissue injuries, and hepatocytes are susceptible to $\mathrm{H}_{2} \mathrm{O}_{2}$-induced damage. High levels of $\mathrm{H}_{2} \mathrm{O}_{2}$ probably overwhelm cellular antioxidant defenses, leading to cellular dysfunction and cytotoxicity [14]. $\mathrm{H}_{2} \mathrm{O}_{2}$ can induce apoptosis and necrosis in hepatocytes [15], and the relative proportions of the cell death modes may be determined by insult intensity and cell type [11]. We found that $6 \mathrm{~h}$ exposure to $125 \mathrm{\mu M} \mathrm{H}_{2} \mathrm{O}_{2}$ caused apoptosis and necrosis of SNU-761 HCC cells. To explore possible

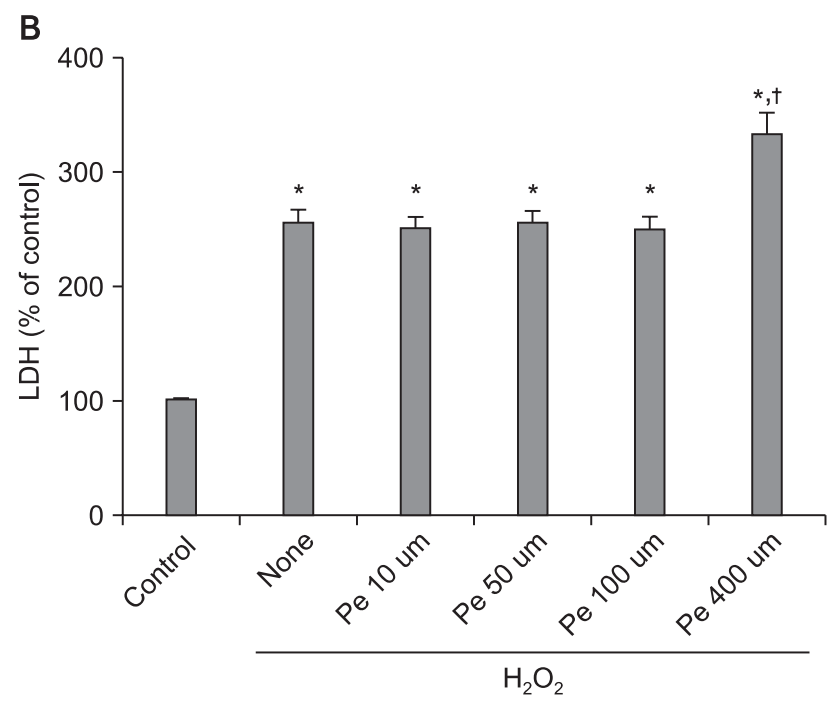

Fig. 1. Effects of propofol and pentobarbital on LDH release from hepatocytes after exposure to $125 \mu \mathrm{M} \mathrm{H}_{2} \mathrm{O}_{2}$ for 6 h. Propofol decreased LDH release in a dose-dependent manner (A), but pentobarbital did not (B). Values are mean \pm SD. $\mathrm{H}_{2} \mathrm{O}_{2}$ : hydrogen peroxide, LDH: lactate dehydrogenase, P: propofol, Pe: pentobarbital. ${ }^{*} \mathrm{P}<0.05$ compared with $\mathrm{H}_{2} \mathrm{O}_{2}$-untreated cells (control), ${ }^{\dagger} \mathrm{P}<0.05$ compared with $\mathrm{H}_{2} \mathrm{O}_{2}$-treated cells (no drug). 


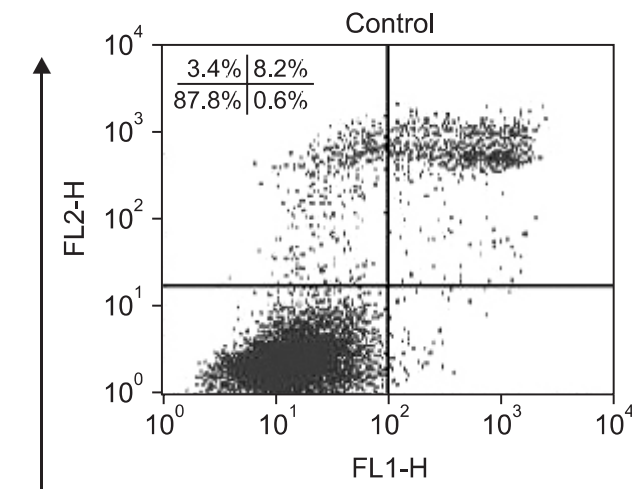

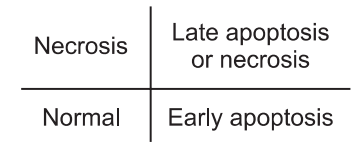
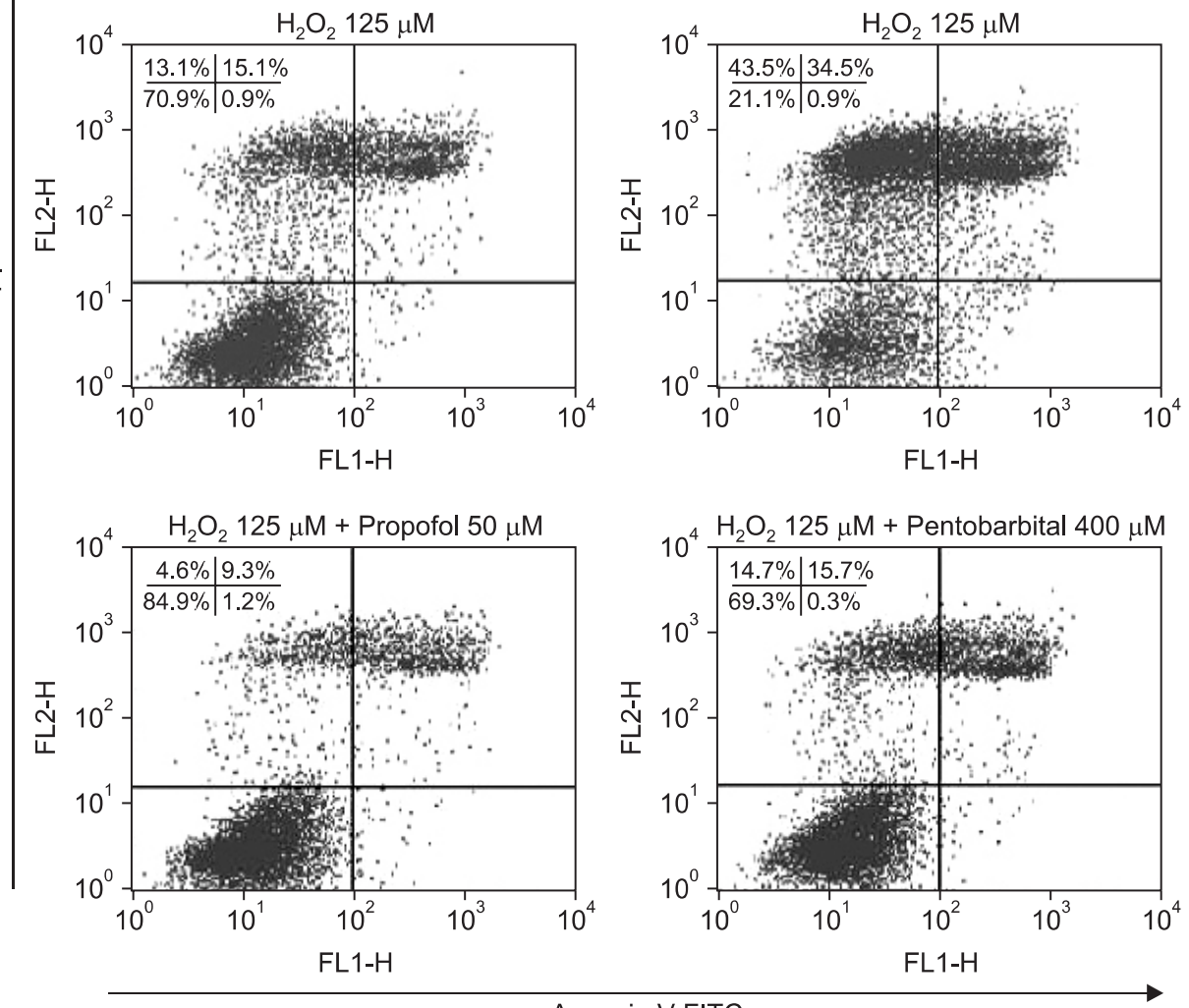

Fig. 2. Apoptosis and necrosis induced by $\mathrm{H}_{2} \mathrm{O}_{2}$ and effects of propofol or pentobarbital on $\mathrm{H}_{2} \mathrm{O}_{2}$-induced cell death in hepatocytes. The figure shows flow cytometric analysis of Annexin V-FITC/PI doubly stained cells. Cells were either untreated (controls) or treated with 125, $250 \mu \mathrm{M} \mathrm{H}_{2} \mathrm{O}_{2}$ for $6 \mathrm{~h}$ or were pretreated with propofol (50 $\mu \mathrm{M})$ or pentobarbital $(400 \mu \mathrm{M})$ for 30 min followed by exposure to $\mathrm{H}_{2} \mathrm{O}_{2}$ $(125 \mu \mathrm{M})$ for $6 \mathrm{~h}$. The percentages of the cell forms mentioned below were calculated using the CellQuest Pro software program (mean values are given; the experiment was performed three times). In each plot, the lower left quadrant represents viable cells, the upper left quadrant necrotic cells, the lower right quadrant early apoptotic cells, and the upper right quadrant necrotic or late apoptotic cells. $\mathrm{H}_{2} \mathrm{O}_{2}$ : hydrogen peroxide, FITC: fluorescein isothiocyanate, PI: propidium iodide. protective effects of propofol in cells under oxidative stress, we chose the range $1-50 \mu \mathrm{M}(0.178-8.90 \mu \mathrm{g} / \mathrm{ml})$ as clinically relevant because peak plasma concentrations of propofol are reportedly $40-60 \mu \mathrm{M}(7.12-10.68 \mu \mathrm{g} / \mathrm{ml})$ at anaesthesia induction and $10-25 \mu \mathrm{M}(1.78-4.45 \mu \mathrm{g} / \mathrm{ml})$ during anaesthesia maintenance $[16,17]$. Our results are not, however, in full agreement with previous studies, which yielded conflicting data regarding the effects of propofol on the liver under oxidative stress [18-20]. Navapurkar and co-workers [17] demonstrated that propofol could protect suspensions of isolated rat hepatocytes from an oxidant insult. Also, Wang and co-workers [20] reported that propofol had an anti-apoptotic effect on human hepatic L02 cells suffering from oxidant stress induced by $\mathrm{H}_{2} \mathrm{O}_{2}$; this was mediated by activation of extracellular signal-regulated kinase pathways. However, in an ischemia/ reperfusion (I/R) model using the precision-cut rat liver-slice technique, propofol did not show any beneficial effect against I/R injury [19]. Reasons for these discrepancies may include the use of different experimental models. For example, liver slices are multi-layered, and include not only hepatocytes, but also other cell types (such as Kupffer cells and neutrophils) that inhibit the antioxidant effects of propofol [19].

In the present study, pentobarbital did not protect hepatocytes from oxidative stress; rather, this drug aggravated stress damage when present at a high concentration $(400 \mu \mathrm{M})$. This concentration is comparable with the plasma level during barbiturate coma. Although central nervous system levels of pentobarbital during drug therapy are largely unknown, 
common therapeutic plasma concentrations have been reported to be $144-323 \mu \mathrm{M}$ [21]. Therefore, we considered $1-400 \mu \mathrm{M}$ of pentobarbital to be the clinically relevant range. Our results are consistent with those of a previous study showing that pentobarbital aggravates neuronal cell damage after combined oxygen and glucose deprivation [6]. Further work exploring the detrimental effects of pentobarbital may be warranted.

When the clinical implications of our data are considered, it may be that propofol is a better anesthetic choice than pentobarbital during surgery that involves temporary interruption of liver blood flow. In addition, pentobarbital has usually been employed to reduce cerebral edema during liver transplantation in FHF patients, but we may be more cautious attitude to use of pentobarbital in liver surgery. Delayed wakefulness and postoperative neurologic examination are caused by the very long drug half-life, and pentobarbital use is also associated with significant hemodynamic disturbances $[7,8]$. Therefore, some recent reports have suggested that propofol might be a useful alternative for reduction of cerebral edema because propofol metabolism is not greatly affected by liver failure $[8,22]$. In the present study, our data support the idea that propofol may be more useful than pentobarbital in patients with FHF. However, a further in vivo study is needed to establish which anaesthetics are suitable for use in hepatic surgery, particularly in FHF cases, during which interruption of liver blood flow is planned, because the in vitro and in vivo effects of anesthetics can differ [23]. Also it is another consideration that we used the tumor cells of human hepatocytes. In other words, different results might have made in our research if we had used normal human hepatocytes.

In conclusion, pentobarbital did not affect apoptosis or necrosis induced by $\mathrm{H}_{2} \mathrm{O}_{2}$, and, at low concentrations, was not cytotoxic for hepatocytes, whereas propofol preconditioning was protective in a dose-dependent manner. Our results show that propofol protects hepatocytes in vitro in the clinically relevant range $10-50 \mu \mathrm{M}$, suggesting potential benefits when the drug is employed during liver surgery, especially in FHF patients.

\section{References}

1. Teoh NC, Farrell GC. Hepatic ischemia reperfusion injury: pathogenic mechanisms and basis for hepatoprotection. J Gastroenterol Hepatol 2003; 18: 891-902.

2. Carden DL, Granger DN. Pathophysiology of ischaemia-reperfusion injury. J Pathol 2000; 190: 255-66.

3. Nagao T, Inoue S, Goto S, Mizuta T, Omori Y, Kawano N, et al. Hepatic resection for hepatocellular carcinoma. Clinical features and long-term prognosis. Ann Surg 1987; 205: 33-40.

4. Maynard ND, Bihari DJ, Dalton RN, Beale R, Smithies MN, Mason
RC. Liver function and splanchnic ischemia in critically ill patients. Chest 1997; 111: 180-7.

5. Czaja MJ. Induction and regulation of hepatocyte apoptosis by oxidative stress. Antioxid Redox Signal 2002; 4: 759-67.

6. Almaas R, Saugstad OD, Pleasure D, Rootwelt T. Effect of barbiturates on hydroxyl radicals, lipid peroxidation, and hypoxic cell death in human NT2-N neurons. Anesthesiology 2000; 92: 76474.

7. Forbes A, Alexander GJ, O'Grady JG, Keays R, Gullan R, Dawling $S$, et al. Thiopental infusion in the treatment of intracranial hypertension complicating fulminant hepatic failure. Hepatology 1989; 10: 306-10.

8. Jalan R. Pathophysiological basis of therapy of raised intracranial pressure in acute liver failure. Neurochem Int 2005; 47: 78-83.

9. Saraste A, Pulkki K. Morphologic and biochemical hallmarks of apoptosis. Cardiovasc Res 2000; 45: 528-37.

10. Vermes I, Haanen C, Steffens-Nakken H, Reutelingsperger C. A novel assay for apoptosis. Flow cytometric detection of phosphatidylserine expression on early apoptotic cells using fluorescein labelled Annexin V. J Immunol Methods 1995; 184: 39-51.

11. Conde de la Rosa L, Schoemaker MH, Vrenken TE, Buist-Homan M, Havinga R, Jansen PL, et al. Superoxide anions and hydrogen peroxide induce hepatocyte death by different mechanisms: involvement of JNK and ERK MAP kinases. J Hepatol 2006; 44: 91829.

12. Lee JH, Ku JL, Park YJ, Lee KU, Kim WH, Park JG. Establishment and characterization of four human hepatocellular carcinoma cell lines containing hepatitis B virus DNA. World J Gastroenterol 1999; 5: 289-95.

13. Fadok VA, Voelker DR, Campbell PA, Cohen JJ, Bratton DL, Henson PM. Exposure of phosphatidylserine on the surface of apoptotic lymphocytes triggers specific recognition and removal by macrophages. J Immunol 1992; 148: 2207-16.

14. Zhang W, Wang M, Xie HY, Zhou L, Meng XQ, Shi J, et al. Role of reactive oxygen species in mediating hepatic ischemia-reperfusion injury and its therapeutic applications in liver transplantation. Transplant Proc 2007; 39: 1332-7.

15. Jaeschke H, Gores GJ, Cederbaum AI, Hinson JA, Pessayre D, Lemasters JJ. Mechanisms of hepatotoxicity. Toxicol Sci 2002; 65: 166-76.

16. Adachi YU, Satomoto M, Higuchi H, Watanabe K. Rapid fluid infusion therapy decreases the plasma concentration of continuously infused propofol. Acta Anaesthesiol Scand 2005; 49: 331-6.

17. Murphy PG, Davies MJ, Columb MO, Stratford N. Effect of propofol and thiopentone on free radical mediated oxidative stress of the erythrocyte. Br J Anaesth 1996; 76: 536-43.

18. Navapurkar VU, Skepper JN, Jones JG, Menon DK. Propofol preserves the viability of isolated rat hepatocyte suspensions under an oxidant stress. Anesth Analg 1998; 87: 1152-7.

19. Shimono H, Goromaru T, Kadota Y, Tsurumaru T, Kanmura Y. Propofol displays no protective effect against hypoxia/ reoxygenation injury in rat liver slices. Anesth Analg 2003; 97: 442-8.

20. Wang H, Xue Z, Wang Q, Feng X, Shen Z. Propofol protects hepatic L02 cells from hydrogen peroxide-induced apoptosis via activation of extracellular signal-regulated kinases pathway. Anesth Analg 
2008; 107: 534-40.

21. Winer JW, Rosenwasser RH, Jimenez F. Electroencephalographic activity and serum and cerebrospinal fluid pentobarbital levels in determining the therapeutic end point during barbiturate coma. Neurosurgery 1991; 29: 739-41.

22. Takizawa D, Sato E, Hiraoka H, Tomioka A, Yamamoto K, Horiuchi $\mathrm{R}$, et al. Changes in apparent systemic clearance of propofol during transplantation of living related donor liver. Br J Anaesth 2005; 95: 643-7.

23. Chen TL, Wang MJ, Huang CH, Liu CC, Ueng TH. Difference between in vivo and in vitro effects of propofol on defluorination and metabolic activities of hamster hepatic cytochrome P450dependent mono-oxygenases. Br J Anaesth 1995; 75: 462-6. 